\title{
Effects of Acid Treatment on the Clay Palygorskite: XRD, Surface Area, Morphological and Chemical Composition
}

\author{
Katiane Cruz Magalhães Xavier ${ }^{\mathrm{a}}$ Maria do Socorro Ferreira dos Santos ${ }^{\mathrm{b}}$, Maria Rita Morais Chaves Santos $^{\mathrm{a}}$, \\ Marilia Evelyn Rodrigues Oliveira a , Maria Wilma Nunes Cordeiro Carvalho ${ }^{\mathrm{c}}$, \\ Josy Antevelli Osajima a, Edson Cavalcanti da Silva Filho ${ }^{\text {a* }}$ \\ anterdisciplinary Laboratory of Advanced Materials, Natural Science Center, \\ Federal University of Piauí- UFPI, CEP 64049-550, Teresina, PI, Brazil \\ ${ }^{\mathrm{b}}$ Technology Center, Federal University of Piauí - UFPI, CEP 64049-550, Teresina, PI, Brazil \\ ${ }^{\mathrm{C}}$ Chemical Engineering Department, Federal University of Campina Grande - UFCG, \\ CEP 58429-900, Campina Grande, PB, Brazil
}

Received: June 18, 2013; Revised: March 18, 2014

\begin{abstract}
The palygorskite is an aluminum-magnesium silicate that has a fibrous morphology. Their physicochemical characteristics are the result of high surface area, porosity and thermal resistance which make it an attractive adsorbent. Its adsorption capacity can be increased through chemical reactions and/or heat treatments. The objective of this work is to verify the effects of acid activation on the palygorskite, treated with $\mathrm{HCl}$ at $90^{\circ} \mathrm{C}$ at concentrations of 2, 4 and $6 \mathrm{~mol} \mathrm{~L}^{-1}$ in 2 and 4 hours, with clay/acid

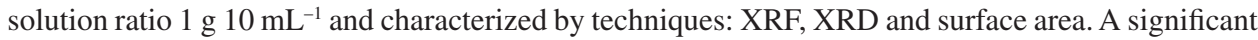
increase in specific surface area was observed in the sample treated with $\mathrm{HCl}$ at the concentration $6 \mathrm{~mol} \mathrm{~L}^{-1}$. The changes were more pronounced at stricter concentrations of acidity, with decreasing intensity of reflection of the clay indicated in the XRD. These changes were confirmed in the XRF with the leaching of some oxides and with increasing concentration of $\mathrm{SiO}_{2}$.
\end{abstract}

Keywords: Palygorskite clay, acid-activation, characterization.

\section{Introduction}

Palygorskite is a crystalline hydrated magnesium aluminium silicate that exists in nature as a fibrous mineral with large surface area, excellent chemical stability and strong adsorption properties. It consists of two layers of tetrahedral silica linked by magnesium ions in an octahedral configuration, connected by a continuous plane of tetrahedral basal oxygen atoms ${ }^{1}$. The tetrahedral basal oxygen atoms invert apical direction at regular intervals coordinating talc like ribbons. Each talc-like ribbon alternates with channels along the fiber axis ${ }^{2}$.

The palygorskite has the theoretical formula: $\mathrm{Si}_{8} \mathrm{Mg}_{5} \mathrm{O}_{20}$ $(\mathrm{OH})_{2}\left(\mathrm{OH}_{2}\right)_{4} \cdot 4 \mathrm{H}_{2} \mathrm{O}$, which was first proposed by Bradley ${ }^{3-5}$. However, the chemical composition of these mineral clays varies within certain limits according to their origin. Considerable amounts of $\mathrm{Al}^{+3}$ can replace $\mathrm{Mg}^{+2}$ in the octahedral sheet. Thus, depending on the degree of isomorphous substitution, the ideal palygorskite rich in magnesium or aluminum would be: $\mathrm{Si}_{8}\left(\mathrm{Mg}_{5-3 \mathrm{x}} \mathrm{Al}_{2 \mathrm{x}}\right)$ $\mathrm{O}_{20}(\mathrm{OH})_{2}\left(\mathrm{OH}_{2}\right)_{4} \cdot 4 \mathrm{H}_{2} \mathrm{O}$, whose structure contains three forms of water in its structure: zeolitic water, coordinated and structural water ${ }^{6}$.

In addition to aluminum, other cations may replace magnesium, albeit of a less extensive form. The presence of trivalent cations into octahedral positions creates an excess

*e-mail: edsonfilho@ufpi.edu.br of positive charge which is compensated by empty spaces caused by two trivalent ions, whose chemical composition of the palygorskite varies according to the origin of the sample ${ }^{7}$ The differences in the ratio of divalent/trivalent cation, which alter the chemical composition of the palygorskite, will affect the proportion of trivalent ions located at the ends and within the octahedral sheet, and carry the differences in its behavior and composition, particularly in response to acid leaching 8 .

Appropriate acid treatments of clay minerals modify their surface area and/or the number of acid sites by disaggregation of clay particles, elimination of mineral impurities, removal of metal-exchange cations and proton exchange. For palygorskite, acid activation can eliminate impurities, change its composition, generate more active $\mathrm{OH}^{-}$groups on its surface, increase its area and pore volume as well as the number of adsorption sites by disaggregation of palygorskite paticles ${ }^{9-11}$. Thus, acid treatment have been used for increasing the surface area of clay minerals and for obtaining from these minerals solids with a high numbers of acid centers, properties that influence the application of these materials in descolourization, adsorption and catalysis in reactions in which catalysis with acidic properties are requerid $^{10}$.

The objective of this research is to analyze the structural changes developed in the palygorskite after treatment by 
hydrochloric acid at three different concentrations with variations in time and with temperature of $90{ }^{\circ} \mathrm{C}$ through the use of the techniques: XRF, XRD and specific surface area $(\mathrm{BET})$.

\section{Experimental}

\subsection{Materials}

It was used a sample of Palygorskite, from Guadalupe, PI, provided in the form of agglomerate by the Itaoeste company, which has a cation exchange capacity (CEC) of 40 meq/100g, and with structural formula: $\left(\mathrm{Si}_{8.05}\right)\left(\mathrm{Mg}_{1.59} \mathrm{~A}\right.$ $\left.1_{1.74} \mathrm{Fe}_{0,32} \mathrm{Ti}_{0.084} \mathrm{Mn}_{0.023}\right)\left(\mathrm{K}_{0.052}\right) \mathrm{O}_{20}(\mathrm{OH})_{2}\left(\mathrm{OH}_{2}\right)_{4} \cdot \mathrm{nH}_{2} \mathrm{O}^{[3]}$. The natural clay dried at $25^{\circ}$, and ground was sieved entirely on 200 mesh sieve. The hydrochloric acid ( $\mathrm{HCl}$ ) 35\% PA (VETEC) and distilled water was utilized in this work.

\subsection{Acid activation}

For the activation assays, it was treated, under magnetic stirring, an amount of palygorskite in hydrochloric acid at concentrations of $2,4,6 \mathrm{~mol} \mathrm{~L}-1$ at $90{ }^{\circ} \mathrm{C}$ with reaction times of 2 or 4 hours ${ }^{9-11}$. The mixture was stirred in a becker with a cover in order in order to maintain the constant volume of solution used, with the mass ratio of the clay/solution volume, $1 \mathrm{~g}$ : $10 \mathrm{~mL}$. Initially, aqueous solution was prepared in the requerid concentration with hydrochloric acid, which was added to the sample $(10 \mathrm{~g})$ and crushed, which was contained in a glass container. After completion of the reaction, the mixtures obtained were vacuum filtered (Buchner funnel and conical flask), and washed with distilled water until the $\mathrm{pH}$ of the filtrates remained at around 7 . The materials obtained were dried in an oven at $60 \pm 5^{\circ} \mathrm{C}$ and after 24 hours were disaggregated in a mortar. The activated samples were characterized by X-ray fluorescence, X-ray diffraction and surface area.

\subsection{Characterization of the palygorskite}

The XRF analysis was performed on spectrometer for X-ray fluorescence - (WDS) model BOL - FRX - 030. The sample was prepared by fusion at a dilution of $1 / 10$ and used as a flux, a mixture of lithium borate $\left(\mathrm{Li}_{2} \mathrm{~B}_{4} \mathrm{O}_{7}-\mathrm{LiBO}_{2}\right)$. The $\mathrm{X}$-Ray Diffraction (XRD) was performed on equipment LabX - XRD 600, Shimadzu, with $\mathrm{Cu}-\mathrm{K} \alpha$ radiation $(\lambda=1.5406 \AA)$ with $2 \theta$ in the range of $5^{\circ}$ to $75^{\circ}$, with scan rate of $2 \% \mathrm{~min}$ and total exposure time of 40 minutes. The surface area was determined in an apparatus for physical adsorption of nitrogen Quantachrome NOVA 4200, using BET method for processing the data. Secondary electron images were acquired with a JEOL JSM 6360LV scanning electron microscope, operating at $20 \mathrm{kV}$.

\section{Results and Discussion}

\subsection{X-ray diffraction}

The diffractograms of the natural clay and acid treated are shown in Figure 1, of which the main indication of the presence of palygorskite occurs by the appearance of peak at $8.5^{\circ}(1.05 \mathrm{~nm})$. Besides this, other peaks at $14.0^{\circ}(0.62 \mathrm{~nm})$ and $28.1^{\circ}(0.32 \mathrm{~nm})$ are also observed in the sample of the natural. Besides the palygorskite there is also the presence of quartz, evidenced by the peak around $26.6^{\circ}(0.34 \mathrm{~nm})$. Table 1 shows a comparison between data palygorskite used in this work and data from crystallographic card (JCPDSICCD 00-031-0783) of Clay, revealing that there are no differences between them.

The intensity of the peaks characteristic at $8.5^{\circ}$ $(1.051 \mathrm{~nm}), 14.0^{\circ}(0.636 \mathrm{~nm})$ and $28.1^{\circ}(0.32 \mathrm{~nm})$ decreased progressively in intensity with increasing acid concentration in the experimental conditions established, but does not disappear. This is explained because when the acid concentration is increased to treat a decrease in intensity of the characteristic peak of palygorskite $\left(8.5^{\circ}\right)$, a fact caused by the change of the crystalline structure and followed by leaching in octahedral and tetrahedral sheets ${ }^{3,12,13}$.

The basal distances of the activated samples are approximately equal to the natural sample; however there are small displacements, as for example in the $\mathrm{HCl}$ sample - $4 \mathrm{~mol} \mathrm{~L}-1 / 4 \mathrm{H} / 90{ }^{\circ} \mathrm{C}$, which occurs a displacement of 1.03 to $1.00 \mathrm{~nm}$.

In the activated samples under more intense conditions of temperature of $90{ }^{\circ} \mathrm{C}$ and a time of 4 hours it is observed that the peaks of palygorskite become broader, indicating the loss of crystallinity. At the same time, it was observed through the diffractograms, an increase in insoluble impurities in the sample, and the main reflections correspond to quartz which were found and become more intense with increasing acid attack, progressing in both sets of samples, indicating that the acid attack occurs only on the palygorskite, with the decrease in the intensity peaks relating to clay, with a consequent decrease in crystallinity, the only observations verified ${ }^{14}$.

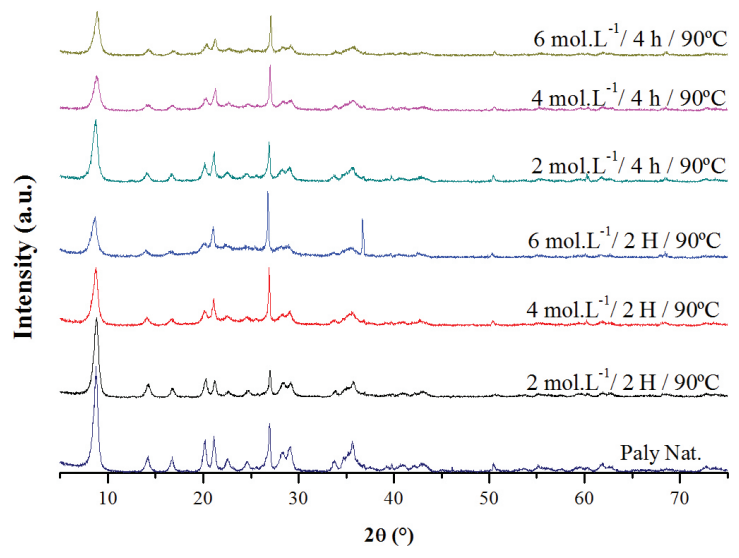

Figure 1. Diffractogram of natural palygorskite and activated with $\mathrm{HCl}$.

Table 1. Comparison of crystallographic planes of parlygorkite.

\begin{tabular}{ccc}
\hline Peaks & Crystallographic Card & Palygorskite (This work) \\
\hline 8.5 & $1.04 \mathrm{~nm}$ & $1.05 \mathrm{~nm}$ \\
14.0 & $0.63 \mathrm{~nm}$ & $0.62 \mathrm{~nm}$ \\
28.1 & $0.31 \mathrm{~nm}$ & $0.32 \mathrm{~nm}$ \\
26.6 & $0.34 \mathrm{~nm}$ & $0.34 \mathrm{~nm}$ \\
\hline
\end{tabular}




\subsection{XRF analysis}

The results of XRF are shown in Table 2, which shows the chemical compositions of natural and activated palygorskites, where it is observed that $\mathrm{Al}_{2} \mathrm{O}_{3}, \mathrm{Fe}_{2} \mathrm{O}_{3}, \mathrm{MgO}$, and $\mathrm{K}_{2} \mathrm{O}$ are the major constituents of the octahedral sheets of the clay.

The palygorskite is a magnesium silicate, which can be substituted for aluminum in the structure. The natural

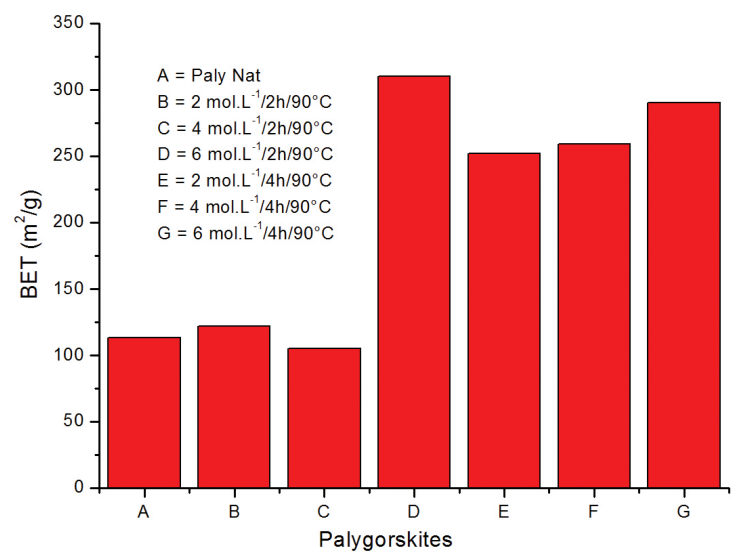

Figure 2. Measurements of surface area of the samples of palygorskite natural and activated. sample has $11.48 \%$ aluminum and $8.28 \% \mathrm{Mg}$. This indicates that the substitution of magnesium by aluminum is larger ${ }^{10}$.

The amounts of $\mathrm{Mg}, \mathrm{Al}$ and Fe were reduced with increasing acid concentration, confirming that the ions $\mathrm{Mg}^{2+}, \mathrm{Al}^{3+}$ and $\mathrm{Fe}^{3+}$ were leached in all activated samples. After acid treatment for a long period of time $(96 \mathrm{~h}$ and $50^{\circ} \mathrm{C}$ ), the hydrochloric acid solution can convert part of the crystals of palygorskite into amorphous silica ${ }^{15}$. However, in this study this result was not observed, it is observed the distinction between the plans and the similarity with the initial crystalline sample, as observed in Figure 1, unlike a diffraction pattern of an amorphous material, which appears only a very broad peak.

Some explanations can be found in studies which affirm that magnesium rich clays are more easily attacked by acids and the octahedral sheets easily undergo leaching, this because its fibers have a smaller size and thus offers a greater specific surface area and a greater number of corners and edges, points which are more easily attacked by acid.

However, samples rich in aluminum, as is the case with clay of this research, have greater fiber length, as well as a larger incidence of trivalent cations that limit the progress of the attack ${ }^{6,15-18}$ Another explanation is found in researches that consider that the $\mathrm{Al}$ occupies the center and the $\mathrm{Mg}$, exclusively, the edges of the octahedral ribbons of the palygorskite which facilitates the leaching of the cations $s^{4,19}$.

When the palygorskite was treated in the condition $\mathrm{HCl}-6 \mathrm{~mol} \mathrm{~L}-1 / 2 \mathrm{~h} / 90{ }^{\circ} \mathrm{C}, 53 \%$ of the $\mathrm{A}_{2} \mathrm{O}_{3}, 70 \% \mathrm{Fe}_{2} \mathrm{O}_{3}$ and

Table 2. Chemical Composition of the clays natural and activated with hydrochloridic acid, under different conditions.

\begin{tabular}{lcccccccc}
\hline \multicolumn{1}{c}{ Treatment } & $\mathbf{M g O}$ & $\mathbf{A l}_{2} \mathbf{O}_{3}$ & $\mathbf{S i O}_{2}$ & $\mathbf{K}_{2} \mathbf{O}$ & $\mathbf{T i O}_{2}$ & $\mathbf{M n O}$ & $\mathbf{F e}_{2} \mathbf{O}_{3}$ & Loss on Fire \\
\hline Natural & 8.28 & 11.48 & 63.67 & 0.32 & 0.87 & 0.21 & 3.27 & 11.90 \\
$2 \mathrm{~mol} \mathrm{~L}^{-1} / 2 \mathrm{H} / 90^{\circ} \mathrm{C}$ & 8.17 & 11.26 & 63.93 & 0.27 & 1.03 & 0.17 & 3.25 & 11.92 \\
$4 \mathrm{~mol} \mathrm{~L}^{-1} / 2 \mathrm{H} / 90^{\circ} \mathrm{C}$ & 5.01 & 7.26 & 71.09 & 0.11 & 0.89 & $\mathrm{ND}$ & 1.66 & 13.98 \\
$6 \mathrm{~mol} \mathrm{~L}^{-1} / 2 \mathrm{H} / 90^{\circ} \mathrm{C}$ & 3.29 & 5.42 & 78.97 & 0.18 & 0.90 & $\mathrm{ND}$ & 0.98 & 10.26 \\
$2 \mathrm{~mol} \mathrm{~L}^{-1} / 4 \mathrm{H} / 90^{\circ} \mathrm{C}$ & 5.72 & 8.09 & 72.10 & 0.14 & 1.11 & $\mathrm{ND}$ & 2.04 & 10.80 \\
$4 \mathrm{~mol} \mathrm{~L}^{-1} / 4 \mathrm{H} / 90^{\circ} \mathrm{C}$ & 5.00 & 7.61 & 73.84 & 0.14 & 0.93 & 0.04 & 1.80 & 10.64 \\
$6 \mathrm{~mol} \mathrm{~L}^{-1} / 4 \mathrm{H} / 90^{\circ} \mathrm{C}$ & 4.79 & 6.97 & 75.65 & 0.15 & 0.97 & $\mathrm{ND}$ & 1.71 & 9.76 \\
\hline
\end{tabular}

$\mathrm{ND}=$ Non-detectable.
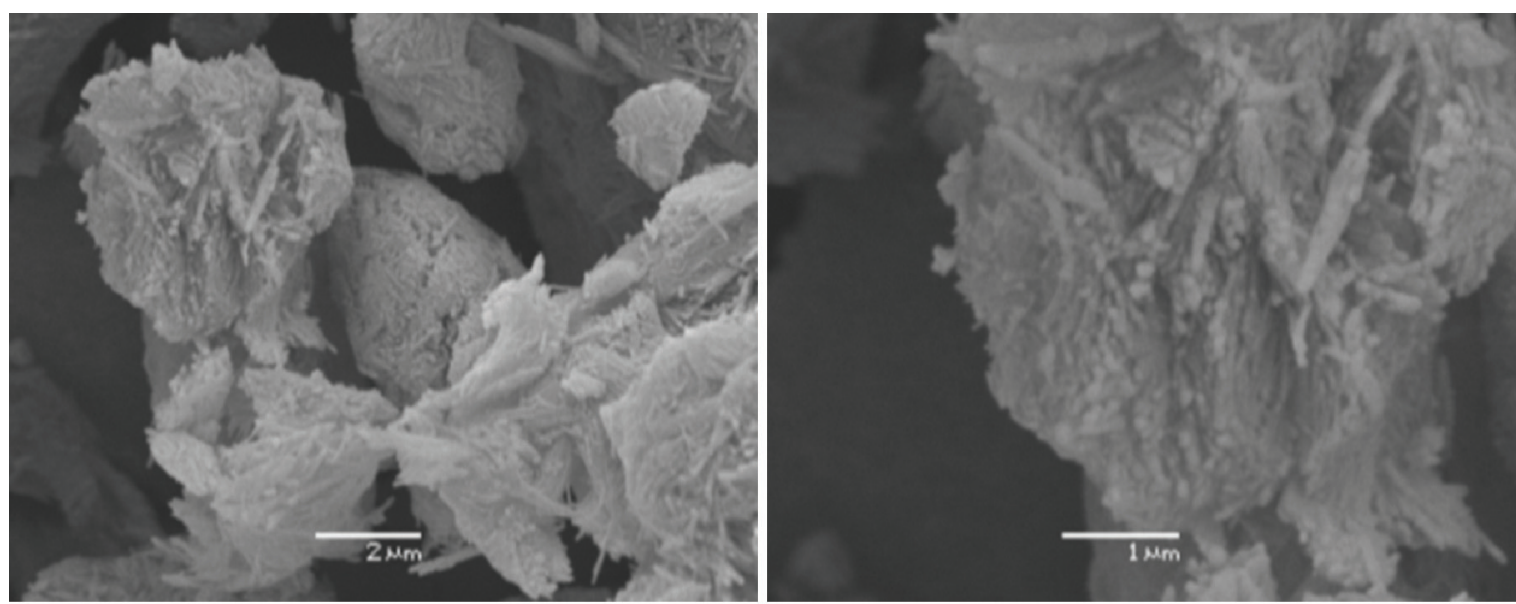

Paly Nat

Figure 3. SEM micrographs of natural palygorskite. 


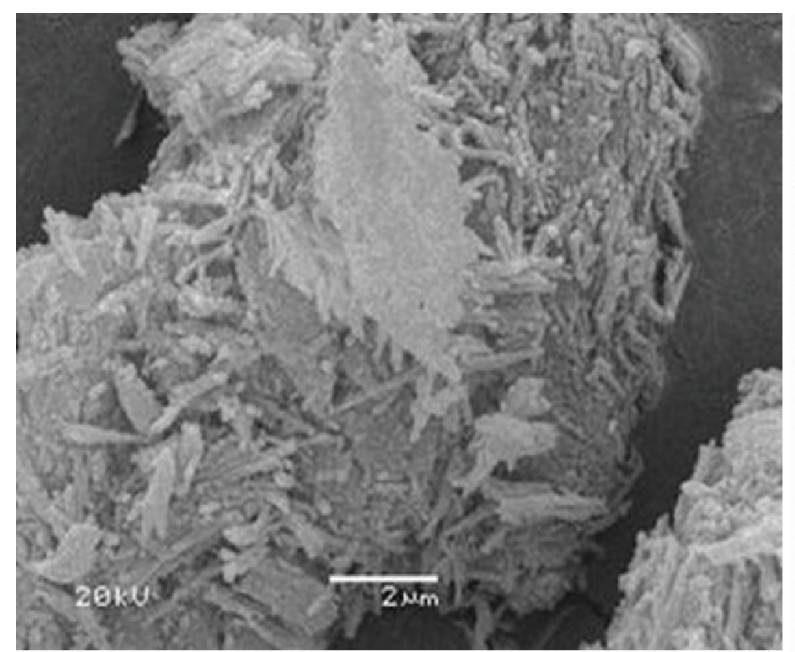

$\mathrm{HCl} / 2 \mathrm{M} / 2 \mathrm{H} / 90^{\circ} \mathrm{C}$

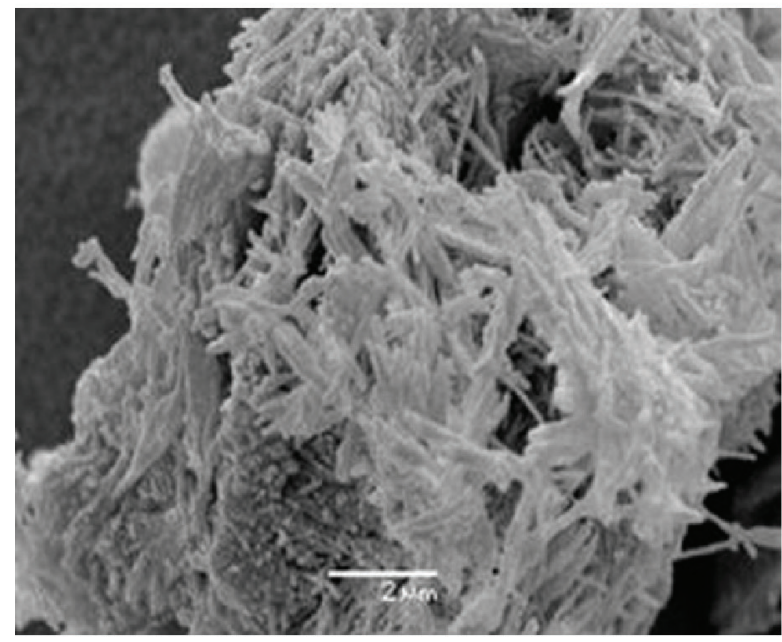

$\mathrm{HCl} / 6 \mathrm{M} / 2 \mathrm{H} / 90^{\circ} \mathrm{C}$

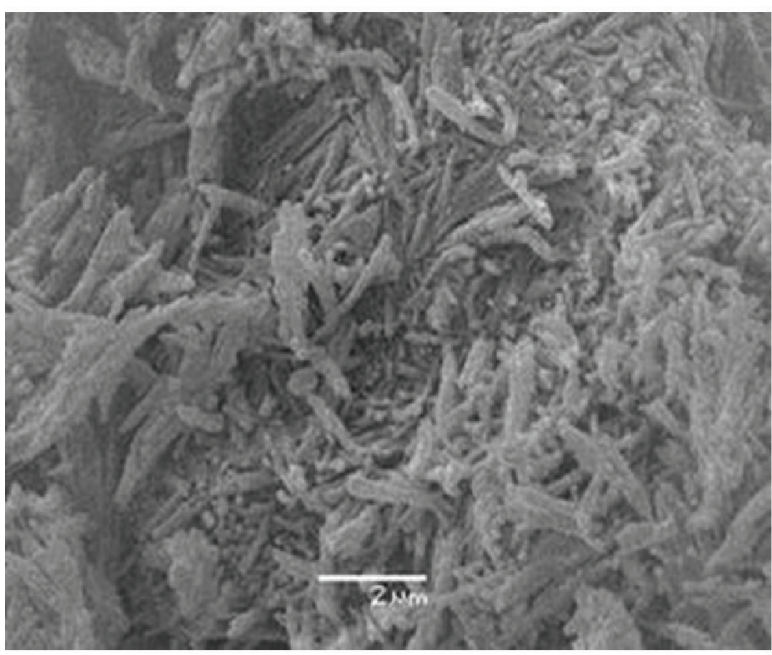

$\mathrm{HCl} / 4 \mathrm{M} / 4 \mathrm{H} / 90^{\circ} \mathrm{C}$

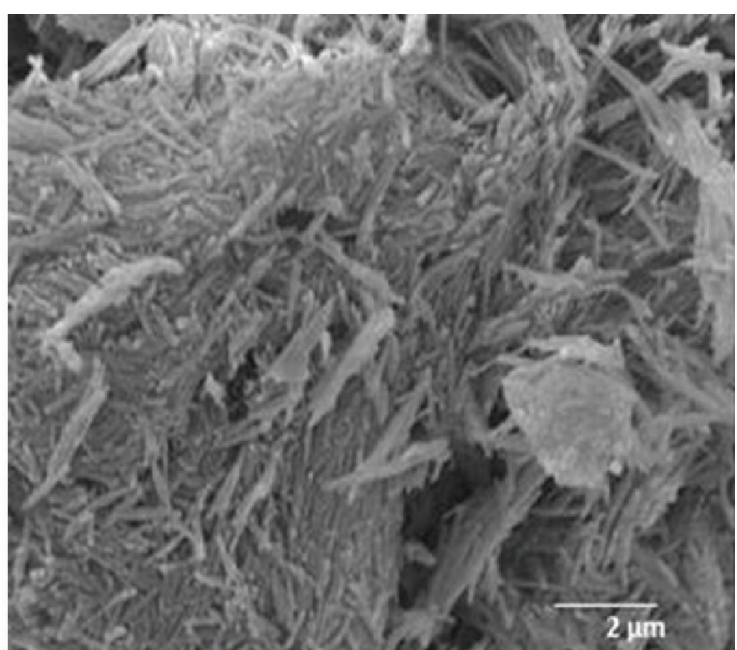

$\mathrm{HCl} / 4 \mathrm{M} / 2 \mathrm{H} / 90^{\circ} \mathrm{C}$

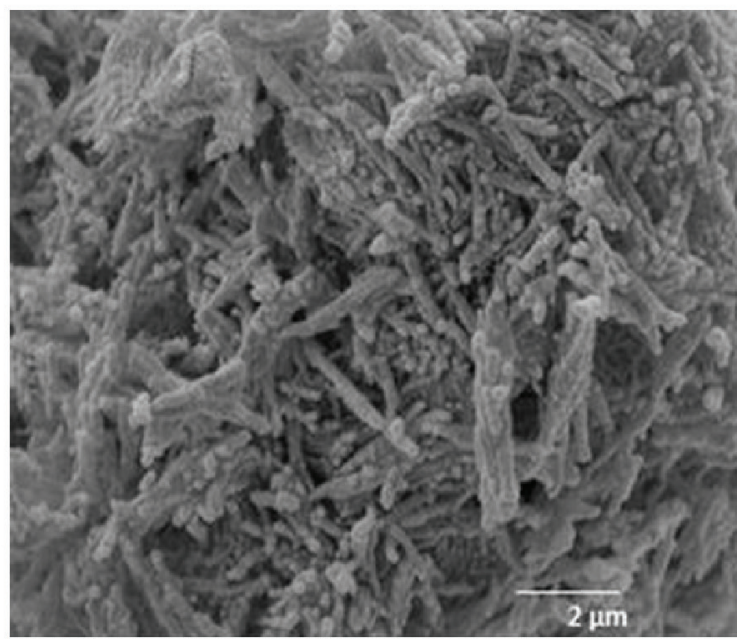

$\mathrm{HCl} / 2 \mathrm{M} / 4 \mathrm{H} / 90^{\circ} \mathrm{C}$

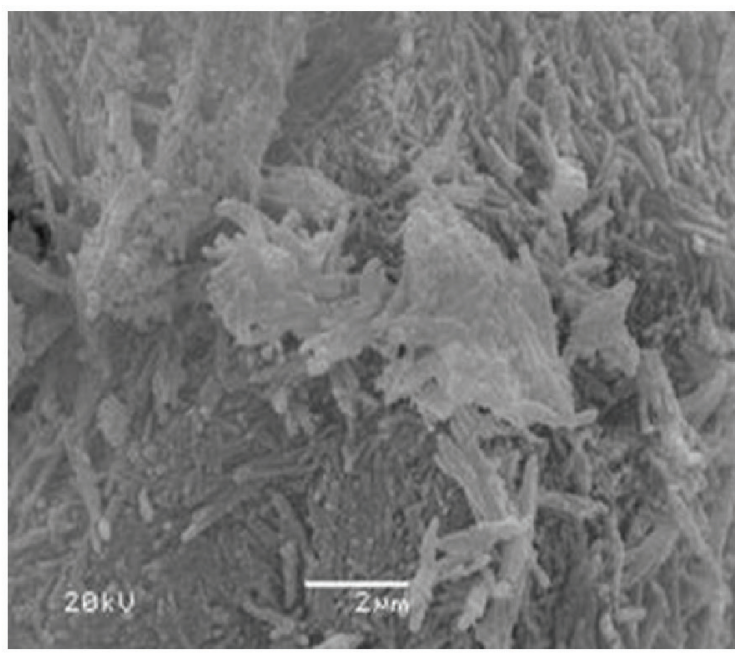

$\mathrm{HCl} / 6 \mathrm{M} / 4 \mathrm{H} / 90^{\circ} \mathrm{C}$

Figure 4. SEM micrographs of samples of activated palygorskites with $\mathrm{HCl}$ at $90{ }^{\circ} \mathrm{C}$. 
$57 \%$ of $\mathrm{MgO}$ were removed from the sample of palygorskite. In this sample was found $78.97 \% \mathrm{SiO}_{2}$. The percentage of the content of $\mathrm{SiO}_{2}$ increases with the exiting of $\mathrm{Mg}, \mathrm{Al}, \mathrm{Fe}$ and others, besides silicon being the dominant constituent in the tetrahedral sheets and being relatively resistant to acid $\operatorname{attack}^{3,20}$.

\subsection{Surface area}

The surface area measurements of natural and activated palygorskite are shown in Figure 2, showing the increased value of the area as the acid treatment progresses. The natural palygorskite has a surface of $113 \mathrm{~m}^{2} \mathrm{~g}^{-1}$. The maximum is $310 \mathrm{~m}^{2} \mathrm{~g}^{-1}$ in the sample $6 \mathrm{M} / 2 \mathrm{H} / 90{ }^{\circ} \mathrm{C}$. The surface area of the sample treated at $6 \mathrm{M} / 4 \mathrm{H} / 90{ }^{\circ} \mathrm{C}$ decreases slightly to a value of $290 \mathrm{~m}^{2} \mathrm{~g}^{-1}$, as shown in Figure 2, it being possible when the treatment time was 2 hours, but there was variation in the surface area when the material was treated in a high concentration $\left(6 \mathrm{~mol} \mathrm{~L}^{-1}\right)$. And treatments using time of 4 hours is observed that as the concentration increases, there is also an increase in surface area due to the strength of the acid.

The increased surface area of the natural palygorskite to acid treated samples is related mainly to the elimination of exchangeable cations and increase of $\mathrm{SiO}_{2}$. The increased surface area to a maximum value and additional decrease were described in the literature for activation with acid on the palygorskite ${ }^{21,22}$ and clays such as: halloysites ${ }^{23}$, and bentonites ${ }^{24}$.

The surface area is one of the most important physicochemical properties of palygorskite, especially when it is used as an adsorbent to remove heavy metals and dyes ions. The specific surface area of the acid activated palygorskite has great influence on the adsorption of $\mathrm{Cu}(\mathrm{II})^{2}$.

\subsection{Morphological analysis}

In order to check the morphology of natural and activated samples with hydrochloric acid are shown in Figures 3 and 4.

\section{References}

1. Post JL and Crawford S. Varied forms of palygorskite and sepiolite from different geologic systems. Applied Clay Science. 2007; 36:232-244. http://dx.doi.org/10.1016/j. clay.2006.10.003

2. Chen $\mathrm{H}$, Zhao $\mathrm{Y}$ and Wang A. Removal of $\mathrm{Cu}$ (II) from aqueous solution by adsorption onto acid-activated palygorskite. Journal of Hazardous Materials. 2007; 149:346-354. PMid:17493750. http://dx.doi.org/10.1016/j.jhazmat.2007.03.085

3. Myriam M, Suárez M and Martín-Pozas JM. Structural and Textural Modifications of Palygorskite and Sepiolite under Acid Treatment. Clay and Clay Minerals. 1998; 46(3):225-231. http://dx.doi.org/10.1346/CCMN.1998.0460301

4. Barrios MS, González LVF, Rodríguez MAV and Pozas JMM. Acid activation of a palygorskite with $\mathrm{HCl}$ : Development of physico-chemical, textural and surface properties. Applied Clay Science. 1995; 10:247-258. http://dx.doi.org/10.1016/01691317(95)00007-Q

5. González F, Pesquera C, Benito I, Mendioroz S and Pajares JA. Mechanism of acid activation of magnesic palygorskite.
From the micrographs displayed in Figure 3, with information about the morphology of the sample of natural palygorskite, it was observed that the clay exhibits fibrous forms, forming clusters of ribbons or needles. Similar images were found by studies in developed palygorskite $^{22}$.

In Figure 4, one can observe that in all samples the acid treatment did not affect severely the fibrous morphology of palygorskite. Long fibers were observed and isolated. From the images were analyzed with the clay mineral particles and made the count. According to the measurements, the average fiber length ranges from 0.3 to 1 microns but the predominant length of 1 micrometers. No significant difference was observed in morphological operating conditions used, even in the most severe cases of concentration and time. This result is in agreement with the results obtained in research that studied the effect of acid activation in palygorskite ${ }^{14,21,24,25}$.

\section{Conclusions}

The progressive destruction of the structures of palygorskite is accompanied with increase in acid concentration. This partial degradation of the structure of the mineral clay under study is due to leaching in the octahedral layer. The acid treatment did not affect severely the fibrous morphology palygorskite. The basal distances of the activated samples are approximately equal to the natural sample, however there are small displacements. All techniques used showed that the more intense the acid attack, the greater the leaching of the octahedral cations, causing chemical and structural changes in the palygorskite, being observed a significant increase in surface area of the solid obtained.

\section{Acknowledgments}

\section{LIMAV/UFPI, CETEM, ITAOESTE, CAPES, CNPQ.}

Clay and Clay Minerals. 1989; 37(3):258-262. http://dx.doi. org/10.1346/CCMN.1989.0370309

6. Gonzalez F, Pesquera C, Blanco C, Benito I, Mendioroz S and Pajares JA. Structural and textural evolution of Al- and Mg-rich palygorskites, I. Under acid treatment. Applied Clay Science. 1989; 4:373-388. http://dx.doi.org/10.1016/01691317(89)90043-4

7. Mifusd A, Rautureau M and Fornés V. Etude De L'eau Dans La Palygorskite A L'aide Des Analyses Thermiques. Clay Minerals. 1978 13:367-374. http://dx.doi.org/10.1180/ claymin.1978.013.4.02

8. Corma A, Mifsud A and Sanz E. Influence of the Chemical Composition and Textural Characteristics of Palygorskite on the Acid Leaching of Octahedral Cations. Clay Minerals. 1987; 22:225-232. http://dx.doi.org/10.1180/ claymin.1987.022.2.10

9. Frini-Srasra $\mathrm{N}$ and Srasra E. Influence of the Chemical Composition and Textural Characteristics of Palygorskite on the Acid Leaching of Octahedral Cations. Desalination. 2010; 250:26-34. http://dx.doi.org/10.1016/j. desal.2009.01.043 
10. Pushpaletha P and Lalithambika M. Modified attapulgite: An efficient solid acid catalyst for acetylation of alcohols using acetic acid. Applied Clay Science. 2011; 51:424-230. http:// dx.doi.org/10.1016/j.clay.2010.12.033

11. Jiang J, Duanmu C, Yang Y, Gu X and Chen J. Synthesis and characterization of high siliceous ZSM-5 zeolite from acidtreated palygorskite. Powder Technology. 2014; 251:9-14. http://dx.doi.org/10.1016/j.powtec.2013.10.020

12. Dombrowsky T and Henderson J. Abstracts of the 11th International Clay Conference. Ottawa: Carleton University, 1997.

13. Grim RE. Clay Mineralogy. New York: McGraw-Hill, 1968.

14. Jiang J, Feng L, Gu X, Qian Y, Gu Y and Duanmu C. Synthesis of zeolite A from palygorskite via acid activation. Applied Clay Science. 2012; 56:108-113. http://dx.doi.org/10.1016/j. clay.2011.10.014

15. Chen TH, Xu HF, Peng SC, Wang JQ and Xu XC. Nanometer Scale Study on Reaction of Palygorskite with Acid:Reaction Mechanism and Change of Specific Surface Area. Geological Journal of China Universities. 2004; 10:98-105.

16. Gonzalez F, Pesquera C, Blanco C, Benito I, Mendioroz S and Pajares JA. Structural and textural evolution under thermal treatment of natural and acid-activated Al-rich and $\mathrm{Mg}$-rich palygorskites. Applied Clay Science. 1990; 5:23-36. http:// dx.doi.org/10.1016/0169-1317(90)90004-9

17. Corma A, Mifsud A and Sanz E. Kinetics of the acid leaching of palygorskite; influence of the octahedral sheet composition. Clay Minerals. 1990; 25:197-205. http://dx.doi.org/10.1180/ claymin.1990.025.2.05

18. Nathan Y. Dissolution of Palygorskite by Hydrochloric Acid. Israel Journal Chemical. 1968; 6:275-283. http://dx.doi. org/10.1002/ijch.196800037
19. Güven N, Caillerie JBE and Fripiat JJ. The coordination of aluminum ions in the palygorskite structure. Clays and Clay Minerals. 1992; 40:457-461. http://dx.doi.org/10.1346/ CCMN.1992.0400410

20. Zhang J, Wang Q, Chen $\mathrm{H}$ and Wang A. XRF and nitrogen adsorption studies of acid-activated palygorskite. Clay Minerals. 2010; 45:145-156. http://dx.doi.org/10.1180/ claymin.2010.045.2.145

21. Boudriche L, Calvet R, Hamdi B and Balard H. Effect of acid treatment on surface properties evolution of attapulgite clay: An application of inverse gas chromatography. Colloids and Surfaces, A: Physicochemical and Engineering Aspects. 2011; 392:45-54. http://dx.doi.org/10.1016/j. colsurfa.2011.09.031

22. Gan FQ, Zhou JM, Wang HY, Du CW and Chen XQ. Removal of phosphate from aqueous solution by thermally treated natural palygorskite. Water Research. 2009; 43(11):29072915. PMid:19447464. http://dx.doi.org/10.1016/j. watres.2009.03.051

23. Zhang A, Pan L, Zhang H, Liu S, Ye Y, Xia M et al. Effects of acid treatment on the physico-chemical and pore characteristics of halloysite. Colloids and Surfaces, A: Physicochemical and Engineering Aspects. 2012; 396:182-188. http://dx.doi. org/10.1016/j.colsurfa.2011.12.067

24. Morales-Carrera AM, Varajão AFDC and Stachissini AS. Argilas bentoníticas da península de Santa Elena, Equador: pilarização, ativação ácida e seu uso como descolorante de óleo de soja. Química Nova. 2009; 32:2287-2293. http://dx.doi. org/10.1590/S0100-40422009000900009

25. Lai S, Yue L, Zhao X and Gao L. Preparation of silica powder with high whiteness from palygorskite. Applied Clay Science. 2010; 50:432-437. http://dx.doi.org/10.1016/j. clay.2010.08.019 